\title{
Effects of Particle Size, Stem Component and Genotype on Absorbency of Kenaf (Hibiscus cannabinus L.) Grown in Nigeria for Oil-Spill Clean-Up
}

\author{
Morufat Oloruntoyin Balogun', AbdulGaniy Olayinka Raji2* \\ ${ }^{1}$ Department of Crop Protection and Environmental Biology, University of Ibadan, Ibadan, Nigeria \\ ${ }^{2}$ Department of Agricultural and Environmental Engineering, University of Ibadan, Ibadan, Nigeria \\ Email:kemtoy2003@yahoo.com, ‘abdulganiy.raji@ui.edu.ng, ‘abdulganiyr@yahoo.com
}

How to cite this paper: Balogun, M.O. and Raji, A.O. (2016) Effects of Particle Size, Stem Component and Genotype on Absorbency of Kenaf (Hibiscus cannabinus L.) Grown in Nigeria for Oil-Spill Clean-Up. Agricultural Sciences, 7, 621-629. http://dx.doi.org/10.4236/as.2016.79058

Received: July 11, 2016

Accepted: September 23, 2016

Published: September 26, 2016

Copyright $\odot 2016$ by authors and Scientific Research Publishing Inc. This work is licensed under the Creative Commons Attribution International License (CC BY 4.0).

http://creativecommons.org/licenses/by/4.0/ (c) (i) Open Access

\section{Abstract}

The efficacies of different products made from different parts of the stem of different varieties of kenaf grown in Nigeria as oil absorbents were tested. Particle sizes, genotypes and whether mixed or sole stem core or bast differed among the treatments. The fibre component sank in water, and so was not buoyant; the core was partially buoyant while the mixed fibre and core was completely buoyant. Sorption capacity was the highest in the ground whole stem ( $8.16 \mathrm{~g}$ oil/g sorbent), which also retained (6.31 $\mathrm{g}$ oil/g sorbent) the highest quantity of oil. Sorption and retention of oil were the lowest in the fibre ( 1.66 and $0.69 \mathrm{~g}$ oil/g sorbent, respectively). After the first use, only the ground stem can be used to re-absorb up to $1.97 \mathrm{~g}$ oil/g sorbent of used sorbent. A mixture of genotypes was more absorbent than a single genotype. The implications of these findings in absorbency research are discussed.

\section{Keywords}

Kenaf, Absorbent, Fibre, Genotype, Bast, Sorption

\section{Introduction}

Kenaf (Hibiscus cannabinus L.) is an environment-friendly, renewable fibre crop with numerous industrial uses. It is used in making ropes, sacks, carpets and canvas and as an alternative non-woody material in paper production, being able to produce as much as southern pine. It has food and non-wood fibre uses, such as in particle board production, filtration media, animal feed, and quality improvement of recycled paper, 
among others [1]. Environmental benefits of kenaf include $\mathrm{CO}_{2}$ absorption due to its rapid growth rate which consequently alleviates global warming [2] [3]. Kenaf has also been found useful in toxic waste clean-up, soil remediation, extraction of heavy metals, reduction of soil erosion and absorption of oil spills [4]-[6].

Africa should be the single most relevant region where kenaf should find applicability in oil-spillage clean-up. This is because there is immense oil spillage in Nigeria's Niger Delta. About 1.89 million barrels of petroleum were spilled into the Niger Delta between 1976 and 1996 out of a total of 2.4 million barrels spilled in 4835 incidents (approximately $220,000 \mathrm{~m}^{3}$ ) constituting about $80 \%$ of the spillage and this had risen to over 3 million barrels in 2001 [7] [8]. It was reported that 9 to 13 million barrels had been spilled in Niger Delta since 1958 as in 2010 [9]. This has increased considerably over the years due to operational problems and sabotage (the largest contributor to oil spill in Nigeria). As reported [10], quoting the National Oil Spill Detection and Response Agency (NOSDRA) of Nigeria, over 9343 spills occurred in the last ten years (2006-2015). The largest spill was the Bonga spill, in which the spill area covered more than 923 square kilometers, and no less than 40,000 barrels of crude was spilled into the Atlantic Ocean in 2011. Associated with these spills are losses in animal and plant genetic resources which can accelerate global warming and climate change that are expected to be most felt in Africa. There is also great threat to human health and peaceful co-existence due to scarcity of arable land for farming and reduced livelihoods, severe localised ecological damage to the near-shore community and destruction of plants and animals in the estuarine zone.

In spite of its numerous end use of kenaf and being native to Africa [11], this region produces only $2.1 \%$ of global production while Asia accounts for 95\% [12] and utilization is still at household level with kenaf only planted in home gardens. This shows lack of technology transfer, testing and adoption from advanced to developing countries.

In Nigeria, Kenaf is majorly grown in the Middle belt: Kwara, Benue, Niger, Kaduna, Plateau and Nasarawa states, and the far North: Sokoto, Borno, and Adamawa states, among the thirty-six states of Nigeria. However, it is only used for making ropes and fences while the leaves are grown and eaten as vegetables in salad and the stem is used to make potash [13]. This study was therefore conducted to test the efficacy of kenaf grown in Nigeria for making oil absorbents. The core of kenaf was reported to be efficient in absorbing oil [1], but reports using kenaf fibres for oil absorption were sparse. However, it is reported [14] that structured fibre assemblies, whether synthetic or natural, are the best materials to clean up oil spill. Also, particle size affected absorbency of kenaf core [15]. This study was conducted to test the efficacy of different products made from different parts of the stem of kenaf grown in Nigeria as oil absorbents with a view to confirming and/or improving on some absorbency.

\section{Materials and Methods}

Seeds of 20 accessions of Kenaf were collected from the genebank of the Institute of Agricultural Research and Training (IAR\&T), Ibadan, Nigeria and planted in the Crop 
garden of the Department of Crop Protection and Environmental Biology, University of Ibadan, Nigeria. Planting was done in rows of $600 \mathrm{~cm}$ long at a spacing of $50 \mathrm{~cm}$ between rows and $25 \mathrm{~cm}$ within the rows. Two seeds were planted per hole at a depth of 2 $\mathrm{cm}$. Weeding, watering, thinning and spraying of insecticide was done when necessary. NPK (15:15:15) was applied at a rate of $120 \mathrm{~kg} / \mathrm{ha}$ [16]. Seeds and stem were harvested after five months by cutting at ground level. The fibre was manually separated from the core. The separated bast and core were left to air dry for 8 months. The core was cut into $5 \mathrm{~cm}$ lengths using a cutter/decorticating machine and milled to different particle sizes with a hammer mill. Some of the fibre was spun with the aid of a tumbler/dryer machine for 8 hours; some were ground to different particle sizes while mixtures of the two were also prepared. Whole stems of the 20 genotype mix on one hand, and dried stems (previous year's harvest) of one genotype collected from Sokoto State Agricultural Development Programme were cut into $15 \mathrm{~cm}$ length and ground together. The following products (sorbents) were prepared and used in this study:

1) Spun fibre (Particle size $=2-5 \mathrm{~cm}$ length)

2) Fibre balls (Particle size $=1-3 \mathrm{~cm}$ length)

3) Ground fibre (Powdered fibre)

4) Ground Core (Powdered core)

5) Powdered fibre + powdered core (1:1 weight)

6) Core ground to $1-1.2 \mathrm{~cm}$ particle length (Rough core)

7) Milled core/milled fibre mix (Bagged)

8) Milled core/milled fibre mix (unbagged)

9) Ground whole stem (20 mixed genotypes, bagged)

10) Ground Whole stem (1 genotype, bagged)

In order to test for Efficacies of absorption each of the ten samples were tested as follows:

1) Buoyancy on water.

2) Absorption of oil using a mix of equal portion of each of petrol, diesel, kerosene and spent engine oil to simulate crude oil.

3) Absorption of oil relative to water using $50 \mathrm{~g}$ each of oil mixed with $50 \mathrm{~g}$ of deionized water.

\subsection{Test for Buoyancy (Water Absorption)}

This buoyancy test was necessary to ensure that the kenaf sorbent to be used are the ones that can float in water as oil would, hence can be scooped from the water surface after absorption. It will also ensure that the water course is not further contaminated by products that sank which will also end up affecting marine lives at the bottom of the rivers. The products were poured or placed on deionized water in a transparent glass container and the quantities that sank and floated were noted after one hour.

Transparent plastic, disposable, screw-cap water bottle $(20 \mathrm{~cm}$ Long) were cut open at the bottom part to give a length of $15 \mathrm{~cm}$. Cheese cloth was used to cover the screw end of the bottle and held in place using rubber band. The cap was then screwed in to 
cover the set up which was placed (upside down) on a clean plastic container. Deionized water (reaching $7.5 \mathrm{~cm}$ length of the bottle) was added to each container and $5 \mathrm{~g}$ of each sorbent was poured into the set up. There were 3 replicates per sorbent. After 24 hrs and 15 minutes [14] sorbents that floated in water was recorded as having passed the buoyancy test and scored 1 while those than sunk were scored 0 and failed. Treatments which sunk half way down, or which had part that floated and others sunk were scored 0.5 (partially pass the test).

\subsection{Test for Oil Absorption}

This test was conducted to determine the samples that have the capability to absorb and retain oil. A mix of equal portion of each of petrol, diesel, kerosene and spent engine oil was used to simulate crude oil.

The same set up as above was used, but water was replaced with $50 \mathrm{~g}$ of oil mix. Sorbent products $\left(S_{p}=5 \mathrm{~g}\right.$ ) were poured into the oil. After 4 hours, the screw cap was removed and the weight of oil-soaked sorbent was taken $\left(W_{1}\right)$. Thereafter oil was left to drain through the cheese cloth into a pre-weighed plastic container for 12 hours. The weight of oil soaked sorbent was recorded $\left(W_{2}\right)$. Each oil-soaked sorbent was hardpressed 10 times to release the absorbed oil and the weight of oil released was again recorded $\left(W_{3}\right)$.

The sorption capacity $(S)$, which is the amount of oil absorbed (g) per gram of the sorbent was determined using Equation (1):

$$
S=\frac{W_{1}-S_{p}}{S_{p}}
$$

The retention capacity $(R)$, which is the amount of oil retained $(\mathrm{g})$ per gram of the sorbent was derived using Equation (2):

$$
R=\frac{W_{2}-S_{p}}{S_{p}}
$$

The re-use capacity $(U)$, the ability of each sorbent to release absorbed oil and reabsorb for absorption was also determined using Equation (3):

$$
U=\frac{W_{s}-S_{p}}{S_{p}}
$$

\subsection{Test for Oil Absorption Relative to Water}

This was done on the simulated oil spilled site by mixing equal weights $(50 \mathrm{~g})$ of oil and deionized water in a transparent container. Deionized water $(50 \mathrm{~g})$ was placed in a measuring cylinder and $50 \mathrm{~g}$ of oil was added. The mixture was allowed to equilibrate and settle until the oil floated completely. The relative volumes were noted. Five grams of the sorbent with the highest sorption capacity was bagged in cheese cloth and placed on the mix. After 4 hours, the bagged sorbent was removed and weighed. The relative amounts of oil absorbed were recorded in comparison with an untreated control (oil/water mix without sorbent). 


\subsection{Data Analysis}

Data were analyzed using Analysis of Variance and means were separated at $\mathrm{p}=0.05$.

\section{Results}

\subsection{Tests for Bouyaoncy}

The moisture content of the kenaf stems used in preparing the sorbent samples was $5.2 \%$. The results of the buoyancy of different kenaf-based materials in deionized water are as given in Table 1. In the table Not buoyant (sunk sorbent) is denoted by 0 while 1 denotes buoyant and 0.5 for components that both sunk and floated (observed-partially buoyant).

\subsection{Test for Oil Absorption}

Sorption, retention and re-usability of different kenaf-based materials in simulated crude oil (spent oil, diesel, petrol and kerosene mixture) results are presented in Table 2. Means in each column followed by the same letters are not significantly different at $5 \%$ level of significance $(\mathrm{p}=0.05)$ in both tables.

\subsection{Oil Absorption Relative to Water}

Table 3 shows that the result of the oil and water were absorbed by the sorbent in a mixture of the two. It shows that $82.54 \%$ and $6.24 \%$ of the oil and water were absorbed by the sorbent respectively after 4 hours.

\section{Discussion}

\subsection{Test for Bouyancy}

The sorbents differed significantly for all parameters (Table 1 and Table 2). The spun fibre, fibre balls and powdered fibre, as presented in Table 1, sank right to the bottom

Table 1. Buoyancy of kenaf-based materials in deionized water.

\begin{tabular}{ccc}
\hline Product type & Buoyancy & Remark \\
\hline Spun fibre (2 - $\mathrm{cm}$ particle length) & 0 & Sunk \\
Fibre balls $(1-3 \mathrm{~cm}$ particle length) & 0 & Sunk \\
Powdered fibre & 0 & Sunk \\
Powdered core & 0.5 & Partial \\
Powdered fibre/powdered core mix & 0.5 & Partial \\
Rough core (1 - 1.2 cm particle length) & 0.5 & Partial \\
Milled core/milled fibre mix (bagged) & 0.5 & Partial \\
Milled core/milled fibre mix (unbagged) & 1 & Floated \\
Whole stem grinded (20 mixed genotypes, bagged) & 1 & Floated \\
Whole stem grinded (1 genotype, bagged) & 1 & Floated
\end{tabular}

0 : Not buoyant, 1: buoyant, 0.5 : Both sunk and floated components observed-partially buoyant. Means in each column followed by the same letters are not significantly different at $\mathrm{p}=0.05$. 
Table 2. Sorption, retention and re-usability of kenaf-based materials in spent oil, diesel, petrol and kerosene mixture.

\begin{tabular}{cccc}
\hline Product type & $\begin{array}{c}\text { Sorption } \\
\text { (g sorbent/g oil) }\end{array}$ & $\begin{array}{c}\text { Retention } \\
\text { (g sorbent/g } \\
\text { oil) }\end{array}$ & $\begin{array}{c}\text { Reusability } \\
\text { (g used } \\
\text { sorbent/g oil) }\end{array}$ \\
\hline Spun fibre (2 - 5 cm particle length) & $1.66^{\mathrm{h}}$ & $0.75^{\mathrm{i}}$ & $0.04^{\mathrm{g}}$ \\
Fibre balls (1 - 3 cm particle length) & $1.77^{\mathrm{g}}$ & $0.69^{\mathrm{i}}$ & $0.21^{\mathrm{f}}$ \\
Powdered fibre & $2.31^{\mathrm{f}}$ & $1.93^{\mathrm{g}}$ & $0.41^{\mathrm{e}}$ \\
Powdered core & $3.00^{\mathrm{e}}$ & $2.61^{\mathrm{e}}$ & $0.83^{\mathrm{d}}$ \\
Powdered fibre/powdered core mix & $2.97^{\mathrm{e}}$ & $2.21^{\mathrm{f}}$ & $0.83^{\mathrm{d}}$ \\
Rough core (1 - 1.2 cm particle length) & $1.76^{\mathrm{g}}$ & $1.56^{\mathrm{h}}$ & $0.07^{\mathrm{g}}$ \\
Milled core/milled fibre mix (bagged) & $5.54^{\mathrm{c}}$ & $4.96^{\mathrm{c}}$ & $1.41^{\mathrm{b}}$ \\
Milled core/milled fibre mix (unbagged) & $3.09^{\mathrm{d}}$ & $2.75^{\mathrm{d}}$ & $0.07^{\mathrm{g}}$ \\
Whole stem grinded & & & $0.90^{\mathrm{c}}$ \\
(20 mixed genotypes, bagged) & $8.16^{\mathrm{a}}$ & $5.56^{\mathrm{b}}$ & $1.97^{\mathrm{a}}$ \\
Whole stem grinded (1 genotype, bagged) & $6.83^{\mathrm{b}}$ & $6.31^{\mathrm{a}}$ & 0.001 \\
\hline Error Mean square & 0.002 & 0.002 & \\
\hline
\end{tabular}

Means in each column followed by the same letters are not significantly different at $\mathrm{p}=0.05$.

Table 3. Oil absorption relative to water by the grinded kenaf stem.

\begin{tabular}{lccccc}
\hline Experiment & Measure & & Oil & Water & Total \\
\hline \multirow{2}{*}{$\begin{array}{c}\text { Sorbent-free } \\
\text { control }\end{array}$} & Volume of oil-water mix & $(\mathrm{ml})$ & 63 & 48 & 111 \\
& Volume after 4 hours & $(\mathrm{ml})$ & 63 & 48 & 111 \\
& Absorption & $(\%)$ & 0 & 0 & - \\
\multirow{3}{*}{ With sorbent } & $\begin{array}{c}\text { Volume of oil-water mix before } \\
\text { sorbent addition }\end{array}$ & $(\mathrm{ml})$ & 63 & 48 & 111 \\
& $\begin{array}{c}\text { Volume of oil-water mix remaining } \\
\text { after 4 hours with sorbent }\end{array}$ & $(\mathrm{ml})$ & 11 & 45 & 56 \\
& Absorption & $(\%)$ & 82.54 & 6.24 & - \\
\hline
\end{tabular}

of the water container and were not buoyant. Non buoyant materials may threaten aquatic life if used as oil absorbent on water because hazardous liquids may be transported to the sediment, causing infiltration into the food chain [14]. However, for the rough core, powdered core, powdered fibre mixed with powdered core (equal weight) and the bagged milled fibre mixed with milled core, a part of the product floated on water while a second part sank. It will be worthwhile to separate kenaf core further into core and pith to determine their relative buoyancies since the extent of threat to the food chain if used as sorbent on oil will vary with the proportion of the material (g) that sunk. The unbagged milled fibre mixed with milled core and the whole stem ground together were however completely buoyant (Table 1 ). The disparity between the bagged and unbagged milled mixes may be due to the buoyancy of the bagging material and this should be tested for buoyancy separately. 


\subsection{Oil Absorption}

The highest sorption capacity (Table 2) was recorded when the whole undecorticated stem of 20 assorted genotypes was ground together, as it absorbed $8.16 \mathrm{~g}$ oil//g sorbent. This was followed by, and significantly different from the ground stem of the Sokoto genotype with a sorption capacity of $6.83 \mathrm{~g}$ of oil/g sorbent. This suggests that genotype effects are significant, such that, testing, and breeding for improved sorption capacity will be worthwhile. Also, the absorption capacity of the whole stem is good, as there will be no waste material left during processing of the plant. Similarly when used the sorbent can be converted to briquettes to be used as solid fuel in some processing operations such as palm oil sterilization involving cooking of the palm fruits commonly done in the Niger delta area.

The decorticated stem whose core and fibre, as presented in Table 2, were separately milled and then mixed together in ratio 7:3 (g:g) respectively was next in sorption capacity ( $3.09 \mathrm{~g}$ oil $/ \mathrm{g}$ of sorbent) and this was enhanced by bagging $(5.54 \mathrm{~g})$. Bagging could have reduced the air spaces which are now available for oil sorption or the bagging material itself could be absorbent and this should be considered when deciding on type of bagging material to use for sorbents.

Reducing particle size by grinding the core and fibre into fine powder before mixing did not improve the sorption (2.97 g), but it improved the sorption capacity of sole core ( rough core $=1.76 \mathrm{~g}$ compared to powdered core $=3.0 \mathrm{~g}$ ] and sole fibre (Powdered $=$ $2.31 \mathrm{~g}$, fibre balls $=1.77 \mathrm{~g}$, spun fibre $=1.66 \mathrm{~g}$ ]. As reported [15], absorbency of kenaf core increased to 12 when the particle size was 106 - 425 microns.

The fibre and core milled together, whether earlier decorticated or not, had a synergistic effect which increased their separate sorption capacities (rough core $=1.76 \mathrm{~g}$, fibre $=2.31 \mathrm{~g}$ expected total $=4.07 \mathrm{~g}$; while decorticated and mixed $=5.54 \mathrm{~g}$ and undecorticated ground stem $=8.16 \mathrm{~g}$ ) as presented in Table 2. A number of explanations have been suggested for absorption by fibre by capillary action into the pores created as in a structured fibre assembly [14]. The main driving force for the transport of the bulk of the liquid into a material is the capillary pressure, which is the pressure difference existing across the interface separating two immiscible substrates. It is probable that such pressure and pore spaces were created by a mixture of the core and fibre in this study. Thus, varying the ratio of the core to the fibre may increase/decrease sorption capacity. For genotypic improvement, the core/bast ratio should be evaluated among kenaf germplasm collections as reported earlier [13].

The same trend was observed for oil retention (Table 2), as products with high sorption capacity also retained more oil. However, genotypic effects were significant since sorption is comparable with retention for a single genotype, while sorption capacity is significantly higher than retention capacity for the mixed genotypes. Further research should be conducted on the effect of core to bast ratio on sorption capacity using different genotypes.

Re-usability was highest (Table 2) in the single genotype whose whole stem was ground together (1.97 $\mathrm{g}$ of oil/g of used sorbent). This was followed by the bagged, 
mixture of milled fibre and milled core $(1.41 \mathrm{~g})$. The latter two products should however be tested for the number of times of possible re-use. Other products will re-absorb less than $1 \mathrm{~g}$ of oil/g of used sorbent and may not be efficient for re-use.

\subsection{Oil Absorption Relative to Water}

The stem grinded together which absorbed 13 times more oil than water when in the same mixture is more efficient for cleaning oil spills. This is because it will also be applied on water bodies, with the oil selectively absorbed.

\section{Conclusion}

This study has shown that the stem of kenaf grown in Nigeria can be used to make effective absorbents. Most previous studies reported the use of only the kenaf core in manufacture of absorbents, except [17] who described sole spun kenaf fibre balls as effective absorbents. This study has found both the core and fibre ground together to be useful and more efficient than separated core and fibre. Consequently, production cost and time will be reduced while nothing is wasted. It will, however, be worthwhile to test further by using different oil types. Genotypic effects also seem to impact significantly on sorption capacity of sorbent materials and should be evaluated.

\section{Acknowledgements}

This work was supported by the Alumni Office, United States Department of State, for the 2011 Alumni Engagement Innovation fund grant used to execute the project. We thank Sope Akande, from the Department of Agricultural and Environmental Engineering and A. Emese, Adebisi and Akinsanya of Crop Protection and Environmental Biology at the University of Ibadan, Nigeria for facilitating the laboratory and field works.

\section{References}

[1] Webber, C.L., Bhardwaj, H.L. and Bledsoe, V.K. (2002) Kenaf Production: Fiber, Feed, and Seed. In: Janick, J. and Whipkey, A., Eds., Trends in New Crops and New Uses, ASHS Press, Alexandria, 327-339.

[2] Lam, T.B.T. (2000) Structural Details of Kenaf Cell Walls and Fixation of Carbon Dioxide. Proceedings of the 2000 International Kenaf Symposium, Hiroshima, 13-14 October 2000, 81-90.

[3] Ofoegbu, O. (2012) Kenaf Fibre-RHA Biocomposite: A “Green" Substitute to Asbestos in Sustainable Eco-Construction. AFRREV STECH: An International Journal of Science and Technology, 1, 71-90.

[4] Sameshima, K. (2000) Improvement of Kenaf Core Oil Absorption Property by Heat Treatment at $200^{\circ} \mathrm{C}-500^{\circ} \mathrm{C}$. Proceedings of $3 \mathrm{rd}$ Annual America Kenaf Society Conference, Corpus Christi, 23-25 February 2000, 64-72.

[5] Lartha, M.R., Indirani, R. and Kamaraj, S. (2004) Bioremediation of Polluted Soils-A Review. Agricultural Review, 25, 252-266.

[6] Zhang, G.-Q., Qi, J.-M., Zhang, X.-C., Fnag, P.P., Su, J.G., Tao, A.F., Lan, T., Wu, W.R. and 
Liu, A.M. (2011) A Genetic Linkage Map of Kenaf (Hibiscus cannabinus L.) Based on SRAP, ISSR and RAPD Markers. Agricultural Sciences in China, 10, 1346-1353. http://dx.doi.org/10.1016/S1671-2927(11)60127-2

[7] Dare, E.A. (2013) Environmental Education for Sustainable Human and Resource Development in Nigeria. Mediterranean Journal of Social Sciences, 4, 97-102. http://www.mcser.org/journal/index.php/mjss/article/download/1786/1790

[8] Nwilo, P.C. and Badejo, O.T. (2006) Impacts and Management of Oil Spill Pollution along the Nigerian Coastal Areas. Administering Marine Spaces: International Issues, 119. A Publication of FIG Commission 4 and 7 Group 4.3. International Federation of Surveyors.

[9] Baird, J. (2010) Oil Shame in Africa. Newsweek 27.

[10] Coetzee, R. (2004) Characterization of Kenaf (Hibiscus cannabinus L.) Cultivars in South Africa. M.Sc. Thesis, University of the Free State, Bloemfontein.

[11] Kalejaiye, K. (2015) Nigeria Records 9343 Oil Spill Incidents in 10 Years. http://sweetcrudereports.com/2015/09/02/nigeria-records-9343-oil-spill-incidents-in-10-ye $\underline{\operatorname{ars} /}$

[12] FAO (2003) The Production and Consumption of Kenaf in China. ESC-Fibres Consultation No. 03/6, FAO, Rome.

[13] Balogun, M.O., Raji, J.A. and Akande, S.R. (2008) Morphological Diversity of 51 Kenaf Accessions in Nigeria. Revista Cientifica UDO Agricola, 8, 23-28.

[14] Karan P.C., Rengasamy, R.S. and Das, D. (2011) Oil Spill Cleanup by Structured Fibre Assembly. Indian Journal of Fibre and Textile Research, 36, 190-200.

[15] Zaveri, M.D. (2004) Absorbency Characteristics of Kenaf Core Particles. Textiles and Apparel, Technology and Management, North Carolina State University, Raleigh.

[16] Adeniyan, O.N., Akande, S.R., Balogun M.O. and Saka, J.O. (2007) Evaluation of Crop Yield of African Yam Bean, Maize and Kenaf under Intercropping Systems. American-Eurasian Journal of Agricultural and Environmental Sciences, 2, 99-102.

[17] Shaffer, D.C. and Reed, R.L. (2010) Oil Absorbent Kenaf Balls and Kits, and Methods of Making and Using the Same. United States Patent 7655149B1.

\section{Submit or recommend next manuscript to SCIRP and we will provide best service for you:}

Accepting pre-submission inquiries through Email, Facebook, LinkedIn, Twitter, etc.

A wide selection of journals (inclusive of 9 subjects, more than 200 journals)

Providing 24-hour high-quality service

User-friendly online submission system

Fair and swift peer-review system

Efficient typesetting and proofreading procedure

Display of the result of downloads and visits, as well as the number of cited articles

Maximum dissemination of your research work

Submit your manuscript at: http://papersubmission.scirp.org/

Or contact as@scirp.org 